\title{
Hyperuricemia and Hypertriglyceridemia: Metabolic Basis for the Association
}

\author{
Irving H. Fox, David John, Sandra DeBruyne, Issac Dwosh, and Errol B. Marliss
}

\begin{abstract}
Hypertriglyceridemia has been reported frequently in patients with hyperuricemia and gout. The current studies have evaluated this relationship. To examine whether hypertriglyceridemia leads to hyperuricemia, IV Intralipid was given to three gouty patients. Triglycerides increased from 169 to $700 \mathrm{mg} / \mathrm{dl}$ for three hours but caused no change in serum urate level or urine uric acid and oxypurine excretion. We next examined whether high carbohydrate intake increases serum urate and triglyceride levels. Four obese patients were placed on a $2000 \mathrm{kcal} / \mathrm{d}$ sucrose diet for seven days. The serum urate increased from $6.3 \pm 1.7$ to $7.9 \pm 2.0 \mathrm{mg} / \mathrm{dL}$. The percent uric acid clearance to creatinine clearance decreased from $5.9 \pm 1.3$ to the lowest mean value of $3.7 \pm 1.2$, while serum triglycerides increased from $106 \pm 33$ to $252 \pm 57 \mathrm{mg} / \mathrm{dL}$ and blood lactate from $607 \pm 227$ to $1167 \pm 381 \mu \mathrm{mol} / \mathrm{L}$. A $3000 \mathrm{kcal} / \mathrm{d}$ glucose diet in four other obese subjects produced no change in serum urate levels but increased lactate and triglyceride levels. During an isocaloric sucrose diet in two normal men, the serum urate level increased from 5.3 and 4.0 to peak values of 9.5 and $7.4 \mathrm{mg} / \mathrm{dL}$. The percent uric acid to creatinine clearance decreased from 5.6 and 6.6 to 2.9 and 3.3. The uric acid turnover did not increase. In three gouty patients the mean serum urate increased from $8.5 \pm 1.5$ to $10.6 \pm 1.4 \mathrm{mg} / \mathrm{dL}$ following an isocaloric sucrose diet. The urine uric acid excretion increased from 0.30 and 0.25 to 0.37 and $0.38 \mathrm{mg} / \mathrm{mg}$ creatinine in two patients. The percent uric acid clearance to creatinine clearance decreased from 3.8 to 2.5 in one patient. The serum triglycerides were substantially elevated during the sucrose diet in the normal subjects and the gouty patients. Our studies show that a pure sucrose diet increases both the serum urate and triglyceride levels. The mechanism of the hyperuricemia is decreased renal clearance of uric acid in the obese normal controls and the normal subjects. Increased urate production and decreased uric acid clearance accounted for the hyperuricemia in the gouty patients. The contribution of excessive sucrose ingestion to clinically associated hyperuricemia and hypertriglyceridemia remains to be elucidated.

(c) 1985 by Grune \& Stratton, Inc.
\end{abstract}

$\mathbf{H}$ YPERTRIGLYCERIDEMIA is frequently associated with hyperuricemia and gout (reviewed in 1). Although the basis for this association is not established, the potential mechanisms include the following: hyperuricemia causes hypertriglyceridemia, hypertriglyceridemia causes hyperuricemia, or another alteration causes both hyperuricemia and hypertriglyceridemia. Previous experiments have examined some of these possibilities. Hyperuricemia itself does not increase plasma lipids. ${ }^{2}$ The existence of a disorder, which causes both hyperuricemia and hypertriglyceridemia, is suggested by the observation of both abnormalities in two inborn errors of carbohydrate metabolism, glucose 6-phosphatase deficiency and fructose 1, 6-disphosphatase deficiency. ${ }^{3-6}$ In addition, administration of carbohydrate in the form of a fructose infusion or a high fructose diet increases uric acid synthesis and increases serum urate levels. ${ }^{7-11}$ We have performed experiments to examine the possible metabolic basis for the association between hyperuricemia and hypertriglyceridemia.

\section{MATERIALS AND METHODS}

L ricase and xanthine oxidase were purchased from Sigma Chemical, St Louis. From New England Nuclear, Boston, we purchased $\left[2-{ }^{14} \mathrm{C}\right]$ uric acid $(57 \mathrm{mCi} / \mathrm{mmol})$. Instagel was obtained from Packard Instruments, Downers Grove, Ill. In-line Cathivex filter units $(0.22$ and $0.45 \mu \mathrm{m})$ were obtained from Millipore Corp, Bedford, Mass. All other reagents were of the highest quality commercially available.

\section{Intralipid Infusion}

Three gouty patients with normal renal function were admitted to the Wellesley Hospital (University of Toronto) Clinical Investiga- tion Unit for studies with lipid infusions (Table 1). They were placed on an isocaloric purine-free diet and were off all medications known to alter uric acid synthesis or excretion. Colchicine $0.6 \mathrm{mg}$ was given twice each day to prevent acute attacks of gout. Five days after admission the patients were given an intravenous (IV) infusion of intralipid. After an overnight fast, an IV line was inserted and 0.87 percent saline was run at the rate of $100 \mathrm{~mL}$ per hour. The following sequence was used to elevate plasma triglyceride levels: Two hour saline infusion; priming dose of $10 \%$ Intralipid $(0.15 \mathrm{~g} / \mathrm{kg})$ given IV for five minutes; and one hour later this same dose of Intralipid was given followed by an infusion of $20 \mathrm{~g}$ of Intralipid (Kabi Vitrum, Berkeley, Calif) per hour for three hours. Blood samples were obtained at five to 60-minute intervals for levels of urate, creatinine, triglyceride, and cholesterol. Urine was collected at hourly intervals throughout the infusion period for measurement of creatinine, uric acid, and oxypurines.

\section{Sucrose Diet}

The influence of a $100 \%$ sucrose diet on uric acid metabolism was examined in studies involving four obese patients, two normal

From the Human Purine Research Center, Departments of Internal Medicine and Biological Chemistry. The University of Michigan. Dr John was an Arthritis Foundation Postdoctoral Fellow. Dr Dwosh is located at the Rheumatic Disease Unit, Queens University, Kingston, Ontario, Canada. Dr Marliss is Director, McGill Nutrition and Food Science Center, Royal Victoria Hospital, Montreal, Quebec, Canada.

Supported by USPHS grant 2R01AM 19764 and 5M01 RR42 and a grant to EBM from the Medical Research Council of Canada MA-4782 and the International Sugar Research Foundation Washington $D C$.

Address reprint requests to Dr Irving $H$. Fox, Clinical Research Center, W4642, Box 055, University Hospital, Ann Arbor, MI 48109 .

(c) 1985 by Grune \& Stratton, Inc.

0026-0495/85/3408-0009\$03.00/0 
Table 1. Study Subjects

\begin{tabular}{|c|c|c|c|c|c|c|}
\hline Patient & Sex & $\begin{array}{l}\text { Age } \\
\text { (vr) }\end{array}$ & $\begin{array}{c}\text { Weight } \\
\text { (kg) }\end{array}$ & $\begin{array}{l}\text { Serum Urate } \\
\text { (mg/dL) }\end{array}$ & $\begin{array}{l}\text { Urinary } \\
\text { Uric Acid } \\
\text { (g/d) }\end{array}$ & Diagnosis \\
\hline \multicolumn{7}{|c|}{ Intralipid Infusion } \\
\hline W.M. & $M$ & 47 & 58.0 & 5.8 & 0.4 & Gout \\
\hline A.M. & $M$ & 55 & 78.3 & 6.7 & 0.4 & Gout \\
\hline$F$ & $\mathbf{M}$ & 64 & 104.5 & 8.1 & 0.5 & Gout \\
\hline \multicolumn{7}{|c|}{ Sucrose Diet $(\mathrm{g} / \mathrm{kg})$} \\
\hline$R(5.2)$ & $F$ & 42 & 94.5 & 3.8 & 0.5 & Obesity \\
\hline$N(3.9)$ & $F$ & 40 & 126.5 & 7.3 & 1.0 & Obesity \\
\hline $\mathrm{B}(4.5)$ & $F$ & 39 & 110.1 & 6.8 & 0.8 & Obesity \\
\hline$L(3.1)$ & $\mathbf{M}$ & 42 & 159.5 & 7.4 & 0.8 & Obesity \\
\hline$W(9.2)$ & $\mathbf{M}$ & 22 & 68.8 & 4.0 & 0.3 & Normal \\
\hline $\mathrm{G}\{6.6\}$ & $M$ & 23 & 97.4 & 5.3 & 0.4 & Normal \\
\hline $\mathrm{G}(5.7)$ & $\mathbf{M}$ & 54 & 120.0 & 10.2 & 0.3 & Gout \\
\hline$A(3.9)$ & $\mathbf{M}$ & 58 & 86.7 & 7.4 & 0.5 & Gout \\
\hline$K(6.0)$ & $\mathbf{M}$ & 73 & 87.9 & 7.9 & 0.4 & Gout \\
\hline \multicolumn{7}{|c|}{ Glucose Diet $(\mathrm{g} / \mathrm{kg})$} \\
\hline $\mathrm{B}(7.3)$ & M & 50 & 101.9 & 5.7 & 0.7 & Obesity \\
\hline$T(5.6)$ & $F$ & 23 & 134.8 & 5.0 & 0.7 & Obesity \\
\hline \multicolumn{7}{|l|}{ Cau } \\
\hline (6.9) & M & 47 & 108.3 & 8.1 & 0.6 & Obesity \\
\hline \multicolumn{7}{|l|}{ Cat } \\
\hline$(6.4)$ & $F$ & 34 & 116.8 & 6.5 & 0.5 & Obesity \\
\hline
\end{tabular}

subjects and three gouty patients (Table 1). All study subjects had normal renal function and discontinued use of any drugs known to alter uric acid metabolism or excretion ten days prior to admission. Colchicine ( $0.6 \mathrm{mg}$ twice a day) was given to the gouty patients to prevent acute gouty arthritis. Urines were collected continuously on a 24-hour basis. Routine surveillance of vital signs and routine biochemistry assured the safety of the dietary alterations.

Three females and one male were admitted to the Clinical Investigation Unit of the Toronto General Hospital (University of Toronto). They were placed on a 2000 calorie sucrose diet (3.1 to 5.2 $\mathrm{g} / \mathrm{kg}$ ). The diet consisted of a flavored solution of sucrose divided up into four doses of equal amounts for seven days.

Three overweight patients with gouty arthritis and two normal controls with normal body weight were admitted twice to the Clinical Research Center at The University of Michigan Hospital. On one admission, patients were placed on a weight-maintenance. isocaloric, purine-free diet with $10 \%$ to $12 \%$ protein and $15 \%$ to $20 \%$ sucrose. On another admission these subjects were placed on an isocaloric diet containing $100 \%$ sucrose (gouty subjects, 3.9 to 6.0 $\mathrm{g} / \mathrm{kg}$; normal control subjects, 6.6 to $9.2 \mathrm{~g} / \mathrm{kg}$ ). Daily serum glucose, triglyceride, creatinine, uric acid and 24-hour urine collections for uric acid, creatinine, and oxypurines were obtained. Three times weekly venous samples for whole blood lactate were drawn.

The turnover of uric acid on and off a sucrose diet was examined in the two normal subjects. This approach allows the possibility of detecting increased synthesis of uric acid. Three to five days after hospital admission, $10 \mu \mathrm{Ci}$ of $\left[2{ }^{14} \mathrm{C}\right]$ uric acid contained in 0.88 mmol uric acid was administered IV through a $0.22 \mu \mathrm{m}$ Cathivex filter to the two normal subjects. ${ }^{12}$ The filters were flushed with 40 $\mathrm{mL}$ of $0.87 \%$ sodium chloride to ensure delivery of the entire isotope dose. An aliquot consisting of $0.5 \mathrm{~mL}$ of each urine sample was added to $5 \mathrm{~mL}$ of Instagel and counted in a Packard model 3003 liquid scintillation spectrometer.

Analysis of the isotope study was performed according to the formula $A=a\left(I_{i} / I_{0}-1\right)$, where $A$ is the miscible pool, $a$ is the dose of uric acid injected, $\mathbf{I}_{i}$ is the concentration of the isotope injected, and $\mathrm{I}_{0}$ is the concentration of the isotope at time $0 .{ }^{13,14}$ The natural logarithm of the isotope concentrations in the patients' urine are plotted against days and the method of least squares is used to determine the intercept and slope of each straight line. The slope of the line provides a turnover rate expressed as pools replaced per day. The antilog of the intercept estimates the isotope concentration at time zero and allows the miscible pool size to be calculated.

\section{Glucose Diet}

Four additional obese subjects (two females and two males) were admitted to the Clinical Investigation Unit of the Toronto General Hospital for study during seven days of a $3000 \mathrm{kcal} / \mathrm{d}$ diet exclusively of glucose, in the form of a polymer $(5.6$ to $7.3 \mathrm{~g} / \mathrm{kg}$ ). As with sucrose, the flavored solution was taken in four equal doses, at mealtimes and bedtime.

\section{Assays}

The serum urate, urine uric acid, and urine oxypurines were measured by enzymatic spectrophotometric methods. ${ }^{15,16}$ Creatinine was quantified by autoanalyzer method. ${ }^{17}$ Lactate was determined by enzymatic spectrophometric or fluorimetric techniques. ${ }^{18,19}$ Other measurements were performed by standard autoanalyzer techniques.

\section{Statistical Analysis}

Analysis of the data from the obese subjects during a sucrose and glucose diet was performed on CLINFO with a repeated measures analysis of variance using Dunnett's $t$ statistic to compare the other time periods to time $0 .^{20}$ No analysis could be performed on the rest of the studies because of the smaller number of subjects.

\section{RESULTS}

\section{Intralipid Infusion}

Intralipid infusion increased plasma lipids fourfold by 90 minutes (Table 2 ). No substantial change is cvident in serum urate values, urine uric acid and oxypurine excretion, and the uric acid clearance.

\section{Sucrose Diet in Obesity}

Four obese patients were placed on a 2000 calorie sucrose diet for seven days (Table 3). Overall, the most pronounced changes were evident on the fourth day. The serum urate increased from $6.3 \pm 1.7$ to $7.9 \pm 2.0$

Table 2. Intralipid Infusion

\begin{tabular}{lcl}
\hline & \multicolumn{1}{c}{ Baseline } & \multicolumn{1}{c}{$\begin{array}{c}\text { Infusion* } \\
\text { (90 minutes) }\end{array}$} \\
\hline Urate $(\mathrm{mg} / \mathrm{dL})$ & $6.7 \dagger(5.1-8.5) \ddagger$ & $6.9(5.9-8.2)$ \\
Uur $/ \mathrm{Ucr}(\mathrm{mg} / \mathrm{mg})$ & $0.32(0.24-0.42)$ & $0.35(0.32-0.38)$ \\
Cur $/ \mathrm{Ccr} \|(\%)$ & $6.1(4.2-9.2)$ & $6.3(4.4-9.2)$ \\
Uaxy $/$ Ucr $(\mathrm{umol} / \mathrm{mg}) \pi$ & $0.06(0.01-0.12)$ & $0.09(0.02-0.14)$ \\
Triglycerides $(\mathrm{mg} / \mathrm{dL})$ & $169(106-234)$ & $671(603-748)$ \\
\hline
\end{tabular}

Three gouty patients were given an IV infusion of intralipid after an overnight fast. A marked elevation of plasma triglycerides is observed during intralipid infusion. No significant change in uric acid metabolism or excretion is evident

- Urine collected from 60 to 120 minutes

† Mean; $¥$ Range

SUur, filtered load of uric acid; Ucr, filtered load of creatinine

$\|$ Cur, clearance of uric acid; $\mathrm{Ccr}$, clearance of creatinine.

IUoxy, filtered load of oxypurine, Ucr, filtered load of creatinine. 
Table 3. Sucrose and Glucose Diets in Obese Patients

\begin{tabular}{|c|c|c|c|c|}
\hline Day & $\begin{array}{c}\text { Serum } \\
\text { Urate } \\
\text { (mg/dL) }\end{array}$ & $\begin{array}{c}\text { Serum } \\
\text { Triglycerides } \\
\text { (mg/dl) } \ddagger\end{array}$ & $\begin{array}{c}\text { Blood } \\
\text { Lactate } \\
\text { ( } \mu \mathrm{mol} / \mathrm{L})\end{array}$ & $\begin{array}{c}\text { Cur/Ccrt } \\
\text { (\%) }\end{array}$ \\
\hline \multicolumn{5}{|c|}{ Sucrose Diet } \\
\hline 0 & $6.3 \pm 1.7^{*}$ & $106 \pm 33$ & $607 \pm 227$ & $6.6 \pm 1.9$ \\
\hline 2 & $7.0 \pm 1.8$ & $193 \pm 53$ & $1409 \pm 495 \S$ & $4.1 \pm 0.6$ \\
\hline 4 & $7.9 \pm 2.0 \|$ & $252 \pm 57$ & $1167 \pm 381 \S$ & $3.7 \pm 1.2$ \\
\hline 7 & $8.2 \pm 2.6 \|$ & $182 \pm 119$ & $1093 \pm 325 \S$ & $5.1 \pm 3.7$ \\
\hline \multicolumn{5}{|c|}{ Glucose Diet } \\
\hline 0 & $6.3 \pm 1.3$ & $132 \pm 24$ & $898 \pm 191$ & $5.9 \pm 1.2$ \\
\hline 2 & $6.5 \pm 1.0$ & $148 \pm 56$ & $1186 \pm 709 \|$ & $4.3 \pm 0.5$ \\
\hline 4 & $6.6 \pm 0.5$ & $212 \pm 72$ & $1710 \pm 439 \|$ & $4.1 \pm 2.5$ \\
\hline 7 & $6.6 \pm 0.9$ & $242 \pm 116 \|$ & $1803 \pm 460 \S$ & $4.4 \pm 2.7$ \\
\hline
\end{tabular}

Four obese nongouty subjects were placed on a $2000 \mathrm{kcal}$ sucrose diet and four others on a $3000 \mathrm{kcal}$ glucose diet for 7 days.

-Mean \pm SD

tAbbreviations are the same as in Table 2.

$\ddagger$ No statistical analysis done because baseline value during the sucrose diet in one patient is missing

$\S P<0.01 ; \| P<0.05$

$\mathrm{mg} / \mathrm{dL}$ on the seventh day. The percent uric acid clearance to the creatinine clearance decreased from $5.9 \pm 1.3$ to lowest mean value of $3.7 \pm 1.2$, while scrum triglycerides increased from $106 \pm 33$ to $252 \pm$ $57 \mathrm{mg} / \mathrm{dL}$ and blood lactate from $607 \pm 227$ to $1167 \pm$ 38: $\mu \mathrm{mol} / \mathrm{L}$. Serum creatinine did not change with values of $0.8 \pm 0.1$ and $0.8 \pm 0.2$ and $\mathrm{mg} / \mathrm{dL}$ before and during the study, respectively.

\section{Glucose Diet in Obesity}

The four subjects receiving this diet (Table 3 ) did not show increases in mean serum urate levels. There was a decrease in mean percent uric acid clearance to creatinine clearance from $5.9 \pm 1.2$ to the lowest mean value of $4.1 \pm 2.5$. A doubling of blood lactate from
$898 \pm 191$ to $1803 \pm 460 \mathrm{mg} / \mathrm{dL}$ and a rise in mean serum triglycerides from $132 \pm 24$ to $242 \pm 116$ $\mathrm{mg} / \mathrm{dL}$ were observed as well.

\section{Sucrose Diet in Normal Subjects}

During an isocaloric sucrose diet in two normal men (Table 4), the serum urate level increased from 5.3 and 4.0 to peak values of 9.5 and $7.4 \mathrm{mg} / \mathrm{dL}$, while the urine uric acid excretion decreased from 0.25 and 0.24 to 0.20 and $0.18 \mathrm{mg} / \mathrm{mg}$ creatinine. The percent uric acid clearance to creatinine clearance decreased from 5.6 and 6.6 to 2.9 and 3.3 , respectively. There was a rise in serum triglycerides and no consistent change in blood lactate levels.

During studies of urate metabolism using [2${ }^{14} \mathrm{C}$ ] uric acid, the urate pool sizes increased from baseline values of 925 and $1254 \mathrm{mg}$ to 1248 and 1687 $\mathrm{mg}$, respectively (Fig 1). No increase of uric acid turnover is evident. The baseline turnovers were 910 and $1083 \mathrm{mg} / \mathrm{d}$ as compared to 779 and $972 \mathrm{mg} / \mathrm{d}$ on sucrose, respectively.

\section{Sucrose Diet in Gout}

We next examined whether the influence of a sucrose diet on uric acid metabolism is the same in gouty patients as obese and normal subjects (Table 4). In gouty patients the mean serum urate increased from $8.5 \pm 1.5$ to $10.6 \pm 1.4 \mathrm{mg} / \mathrm{dL}$. The urine uric acid excretion increased from 0.25 and 0.30 to 0.37 and $0.38 \mathrm{mg} / \mathrm{mg}$ creatinine in two patients and decreased from 0.31 to $0.21 \mathrm{mg} / \mathrm{mg}$ creatinine in one patient. In one patient the renal clearance of uric acid decreased, while there was no change in the renal clearance of uric acid in two patients. There was a marked increase in

Table 4. Sucrose Diet in Normal Subjects and Gouty Patients

\begin{tabular}{|c|c|c|c|c|c|c|}
\hline & \multicolumn{3}{|c|}{ Serum } & \multicolumn{3}{|c|}{ Urine } \\
\hline & $\begin{array}{c}\text { Urate } \\
\text { (mg/ct) }\end{array}$ & $\begin{array}{c}\text { Creatinine } \\
\text { (mg/dl) }\end{array}$ & $\begin{array}{c}\text { Triglyceride } \\
\text { (mg/ch) }\end{array}$ & $\begin{array}{l}\text { Uur/Ucr" } \\
\text { (mg/mgl }\end{array}$ & 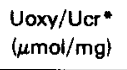 & $\begin{array}{c}\text { Cur/Ccr* } \\
(\%)\end{array}$ \\
\hline \multicolumn{7}{|l|}{ Normal Males } \\
\hline C.W. Baselinet & 4.0 & 1.0 & 67 & 0.24 & 0.08 & 6.6 \\
\hline Sucrose & 7.4 & 1.2 & 125 & 0.18 & 0.08 & 3.3 \\
\hline T.G. Baseline & 5.3 & 1.2 & 97 & 0.25 & 0.10 & 5.6 \\
\hline Sucrose & 9.5 & 1.4 & 124 & 0.20 & 0.10 & 2.9 \\
\hline \multicolumn{7}{|l|}{ Gouty Patients } \\
\hline L.G. Baseline & 10.2 & 1.1 & 310 & 0.30 & 0.16 & 3.3 \\
\hline Sucrose & 11.6 & 1.1 & 737 & 0.37 & 0.15 & 3.5 \\
\hline J.A. Baseline & 7.4 & 0.9 & - & 0.31 & 0.09 & 3.8 \\
\hline Sucrose & 11.3 & 1.3 & - & 0.21 & 0.29 & 2.5 \\
\hline W.K. Baseline & 7.9 & 1.6 & 184 & 0.25 & 0.08 & 5.0 \\
\hline Sucrose & 9.0 & 1.4 & 413 & 0.38 & 0.58 & 6.0 \\
\hline
\end{tabular}

Two normal male subjects and three gouty patients were studied during an isocaloric purine-free diet and isocaloric sucrose diet for an average of nine days. In the two normal men, the serum urate levels increase while the urine uric acid excretion and percent uric acid to creatinine clearance decrease. In the three gouty patients, the serum urate levels increase. In two of the gouty patients, the urine uric acid excretion increases and the uric acid to creatinine clearance increase. In the third patient, the urine uric acid excretion and urine uric acid to creatinine clearance decrease.

- Abbreviations are the same as for Table 2.

†Baseline refers to the values obtained during an isocaloric purine free diet. 


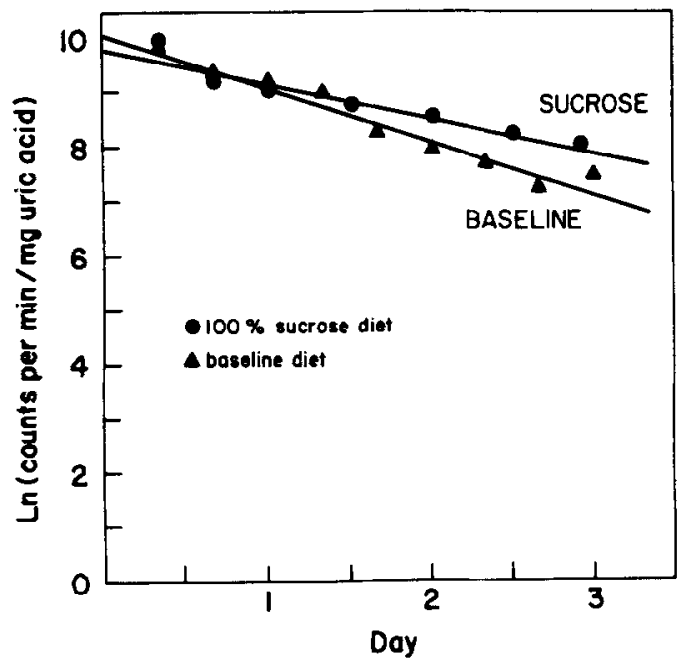

Fig 1. Increased Uric Acid Pool Size During a Pure Sucrose Diet. Two normal subjects were studied for changes in uric acid turnover during an isocaloric sucrose diet. This graph illustrates the representative results in one patient. It can be seen that the uric ecid pool size increases during the sucrose diet from a baseline of $925 \mathrm{mg}$ to $1248 \mathrm{mg}$. The number of pools turned over per day is decreased during the sucrose diet from a baseline of 0.98 to 0.62 . The calculated uric acid turnover is not increased with a baseline value of $910 \mathrm{mg} / \mathrm{d}$ and $779 \mathrm{mg} / \mathrm{d}$ during the sucrose diet. Therefore, there is no rise in uric acid production.

plasma triglyceride levels, but no consistent change in blood lactate levels.

\section{DISCUSSION}

Hypertriglyceridemia occurs frequently in association with gout. ${ }^{1,21-25}$ The metabolic basis for the association between hyperuricemia and hypertriglyceridemia is unclear. One possibility that hyperuricemia itself increases plasma lipids is not supported by experiments performed. ${ }^{2}$ Since lipid abnormalities are absent in first degree relatives of gouty subjects, they may reflect more the lifestyle of the patient than genetic factors. ${ }^{26}$ This proposal is strengthened by the observations that obesity or excessive alcohol intake rather than the underlying hyperuricemia and gout account for the increased serum triglyceride. ${ }^{27-29}$

Our study examined two additional mechanisms which could possibly explain the association between hyperuricemia and hypertriglyceridemia. The data do not support the possibility that hypertriglyceridemia is the cause of hyperuricemia. Acute elevation of serum triglycerides did not modify uric acid synthesis or excretion in the current study or in a previous experiment. ${ }^{30}$ However, these data are not conclusive since infused triglycerides have a different composition and metabolic origin than endogenous triglycerides. In addition, prolonged elevation might have effects not apparent from these acute experiments.

The possibility that excessive sucrose intake may cause both hyperuricemia and hypertriglyceridemia was examined as well. The rationale for this approach is based upon the occurrence of both hyperuricemia and hypertriglyceridemia in patients with glucose 6-phosphatase deficiency ${ }^{3,4}$ and fructose 1,6-diphosphatase ${ }^{5}$ deficiency, inherited disorders of carbohydrate metabolism. In our study either a 2000 calorie sucrose diet or an isocaloric sucrose diet increased the serum urate level in obese patients, normal subjects, and gouty patients. Sucrose-induced elevations of serum urate levels have occurred in other studies as well. ${ }^{31,32}$ In addition, sucrose and glucose increased serum triglycerides in our obese and gouty patients and in subjects of previous reports. ${ }^{32-35}$ Direct, highly significant correlations between serum urate levels and triglyceride concentrations occurred during diets in which the sucrose content was varied from $3 \%$ to $33 \%{ }^{32}$

The fructose moiety of sucrose may be the more important contributor to the hyperuricemia, since the pure glucose diet did not increase the serum urate level despite $50 \%$ more calories. The mechanism for the increased serum urate levels during sucrose intake could be related to increased synthesis of uric acid, decreased uric acid excretion, or both factors operating together. Both mechanisms account for the hyperuricemia of glucose 6-phosphatase deficiency.,4,36 Increased degradation of hepatic ATP secondary to the fructose moiety of sucrose has been proposed to explain the association between sucrose intake and increased urate levels, ${ }^{32}$ since the latter results from IV fructose infusion. ${ }^{7-10,36}$ In contrast, no evidence for elevated uric acid synthesis is evident in the two normal subjects in our study despite the fact that these subjects had the largest quantity of sucrose ingestion. Our studies indicate that the primary mechanism of hyperuricemia during sucrose ingestion is a diminished renal clearance of urate in obese patients and normal subjects. In our obese subjects and in a previous study a sucrose load increased blood lactate levels, ${ }^{37}$ but this is not a consistent observation in our experiments. Hyperlacticacidemia is a well-established factor which decreases uric acid clearance. ${ }^{38}$

Pure sucrose intake increased uric acid synthesis in two gouty patients. This is indicated by the elevation of both serum urate levels and urine uric acid excretion. In one gouty patient there was both decreased clearance of uric acid and increased synthesis of the uric acid precursors hypoxanthine and xanthine. The basis for this heterogenous response of the three gouty patients is not clear. Although the gouty patients are obese, their response is distinct from the obese nongouty subjects. However, studies of more gouty subjects will be necessary to confirm these observations. 
The differences observed in obese, nonobese and gouty subjects may simply reflect the variation in the amount of fructose administered. Our data does not support this possibility (Table 1). The two normal subjects and the obese subjects had a similar quantity of sucrose intake. In addition, the normal subjects who ingested the largest quantity of sucrose, had no evidence for increased production of uric acid (Fig 1, Table 4). Thus, we cannot find evidence that the relative quantity of fructose determines the mechanism of hyperuricemia. On the basis of our data it appears that the gouty subjects may have some alteration in the metabolic handling of fructose such that there are different mechanisms for hyperuricemia.

Despite the relationship between high sucrose intake and increased serum urate levels, epidemiologic studies show no evidence for an association between glucose intolerance and gout ${ }^{39,40}$ or between serum urate and blood sugar levels. ${ }^{34-41}$ In fact, hyperglycemia has uricosuric activity which lowers serum urate levels. ${ }^{39}$, ${ }^{42-46}$ In this study, fasting plasma glucose actually dropped during both sucrose and glucose diets, and oral glucose tolerance improved in the obese subjects (EBM, unpublished data).
Our experiments support the concept that the excessive ingestion of sucrose is an etiological factor which increases both serum urate and serum triglyceride levels. However, the average American ingests sucrose equivalent to $15 \%$ to $20 \%$ of the daily caloric intake. ${ }^{47}$ Therefore, our experiments represent an extreme variation in a short term study, although other studies have directly correlated serum urate levels with triglyceride concentrations during diets containing up to $33 \%$ sucrose. ${ }^{32}$ On the basis of the data available, it must be concluded that the contribution of excessive sucrose ingestion to clinically associated hyperuricemia and hypertriglyceridemia remains unclear. This will require extensive analysis of the dietary habits in the affected patients.

\section{ACKNOWLEDGEMENT}

The authors wish to thank the nurses and dietitians at The University of Michigan Clinical Research Center; The Clinical Investigational Units of the Wellesley Hospital, and The Toronto General Hospital for their management of the patients during this study; Stephen Schmaltz for assisting with data analysis on Clinfo; and Holly Gibson for typing the manuscript.

\section{REFERENCES}

1. Wyngaarden JB, Kelley WN: Gout and Hyperuricemia. New York, Grune \& Stratton, Inc, 1976, pp 21-37

2. Bluestone R, Lewis B, Mervart I: Hyperlipoproteinaemia in gout. Ann Rheum Dis 30:134-137, 1971

3. Kelley WN, Rosenbloom FM, Seegmiller JE, et al: Excessive production of uric acid in type I glycogen storage disease. J Pediatr 72:488-496, 1968

4. Alepa FP, Howell RR, Klinenberg JR, et al: Relationships between glycogen storage disease and tophaceous gout. Am J Med 42:58-66, 1967

5. Pagliara AS, Karl IE, Keating JP, et al: Hepatic fructose-1. 6-diphosphatase deficiency: A cause for lactic acidosis and hypoglycemia in infancy. $\mathrm{J}$ Clin Invest 51:2115-2123, 1972

6. Greene HL, Wilson FA, Hefferan P, et al: ATP depletion, a possible role in the pathogenesis of hyperuricemia in glycogen storage type I. J Clin Invest 62:321-328, 1978

7. Fox [H, Kelley WN: Studies on the mechanism of fructoseinduced hyperuricemia in man. Metabotism 21:713-721, 1972

8. Narins RG, Weisberg JS, Meyers AR: Effects of carbohydrate on uric acid metabolism. Metabolism 23:455-465, 1974

9 Perheentupa J, Raivio K: Fructose-induced hyperuricemia. Lancet 2:528-531, 1967

10. Bode JC, Zelder O, Rumpelt HJ, et al: Depletion of liver adenosine phosphates and metabolic effects of intravenous infusion of fructose or sorbital in man and in the rat. Europ J Clin Invest $3: 436-441,1973$

II. Emmerson BT: Effect of oral fructose on urate production. Ann Rheum Dis 33:276-280, 1974

12. Edwards NL, Recker D, Airozo D, et al: Enhanced purine salvage during allopurinol therapy: An important pharmacologic property in humans. J Lab Clin Med 98:673-683, 1981

13. Benedict JD, Forsham PH, Stetten DW: The metabolism of uric acid in the normal and gouty human studied with the aid of isotopic uric acjd. J Biol Chem 181:183-187, 1949

14. Bowering J, Calloway DH, Margen S, et al: Dietary protein level and uric acid metabolism in normal man. $J$ Nutr 100:249-261, 1970

15. Liddle L, Seegmiller JE, Laster L: The enzymatic spectrophotometric method for determination of uric acid. J Lab Clin Med 54:903-913, 1959

16. Klinenberg JR, Goldfinger S, Bradley KH, et al: An enzymatic spectrophotometric method for the determination of xanthine and hypoxanthine. Clin Chem 13:834-846, 1967

17. R. Technicon AutoAnalyzer method file (method N116). Tarrytown, NY: Technicon Instruments, 1969

18. Girard JR, Cuendet GS, Marliss EB, et al: Fuels, hormones and liver metabolism at term and during the early postnatal period in the rat. J Clin Invest 52:3190-3200, 1973

19. Gutmann I, Wahlefeld AW: L- $(+)$-lactate: Determination with lactate dehydrogenase and NAD. HU Bergmeyer (ed): in Methods of enzymatic analysis, (ed 2). New York, Academic Press, 1974, pp 1464-1468

20. Weiner BJ: Statistical Principles in Experimental Design (ed 2). New York, McGraw Hill Book Company, 1971

21. Bencdck TG: Corrclations of serum uric acid and lipid concentrations in normal, gouty and atherosclerotic men. Ann Int Med 66:851-861, 1967

22. Barlow KA: Hyperlipidemia in primary gout. Metabolism 17:289-299, 1968

23. Berkowitz D: Blood lipid and uric acid interrelationships. JAMA 190:856-858, 1964

24. Berkowitz D: Gout, hyperlipidemia and diabetes interrelationships. JAMA 197:77-80, 1966

25. Feldman EB, Wallace SL: Hypertriglyceridemia in gout. Circulation 29:508-513, 1964 
26. Darlington LG, Slack J, Scott JT: Family study of lipid and purine levels in gout patients. Ann Rheum Dis 41:253-256, 1982

27. Olefsky JM, Farquhar JW, Reaven GM: Reappraisal of the role of insulin in hypertriglyceridemia. Amer J Med 57:551-560, 1974

28. Schonfeld G, Kudzma DJ: Type IV hyperlipoproteinemia: A critical appraisal. Arch Intern Med 132:55-62, 1973

29. Gibson T, Graham R: Gout and hyperlipidaemia. Ann Rheum Dis 33:298-303, 1974

30. Gibson T, Kilbourn K, Horner I, et al: Mechanism and treatment of hypertriglyceridaemia in gout. Ann Rheum Dis 38:3135,1979

31. Solyst JT, Michaelis OE IV, Reiser S, et al: Effect of dietary sucrose in humans on blood uric acid, phosphorous, fructose and lactic acid responses to a sucrose load. Nutr Metab 24:182-188, 1980

32. Israel KD, Michaelis OE IV, Reiser S: Serum uric acid, inorganic phosphorous and glutamic-oxaloacetic transaminase and blood pressure in carbohydrate-sensitive adults consuming three different levels of sucrose. Ann Nutr Metab 27:425-435, 1983

33. Reaven GM: Effect of variation in carbohydrate intake on plasma glucose, insulin, and triglyceride responses in normal subjects and patients with chemical diabetes. Adv Exp Med Biol 119:253-262, 1979

34. Frederickson DS, Levy RI, Lees RS: Fat transport in lipoproteins - an integrated approach to mechanisms and disorders. New Engl J Med 276:273-281, 1967

35. Reiser S, Hallfrisch J, Michaelis OE IV, et al: Isocaloric exchange of dietary starch and sucrose in humans. I. Effects on levels of fasting blood lipids. Am J Clin Nutr 32:1659-1669, 1979

36. Fox IH: Metabolic basis for disorders of purine nucleotide degradation. Metabolism 30:616-634, 1981
37. Kelsay JL, Behall KM, Mitman FW, et al: Effect of sucrose intake on blood and urinary lactate in young women. Nutr Rep Internat 14:179-184, 1976

38. Yu T-F, Sirota JH, Berger L, et al: Effect of sodium lactate infusion on urate clearance in man. Proc Soc Exp Biol Med 96:809-813, 1957

39. Hall AP, Barry PE, Dawber TR, et al: Epidemiology of gout and hyperuricemia. A long term population study. JAMA 42:27-37, 1967

40. Mikkelson WM: The possible association of hyperuricemia and/or gout with diabetes. Arth Rheum 8:853-864, 1965

41. Reed D, Labarthe D, Stallones R: Epidemiologic studies of serum uric acid levels among Micronesians. Arth Rheum 15:38-40, 1972

42. Beckett AG, Lewis JG: Gout and the serum acid in diabetes mellitus. Quart J Med 29:443-458, 1960

43. Herman JB, Keynan A: Hyperglycemia and uric acid. Isr J Med Sci 5:1048-1052, 1969

44. Herman JB, Mount FW, Medalie JII, et al: Diabetic prevalence and serum uric acid. Observations among 10,000 men in a survey of ischemic heart disease in Israel. Diabetes 16:858-868, 1967

45. Padova J, Patchefsky A, Onesti G, et al: The effect of glucose loads on renal uric acid excretion in diabetic patients. Metabolism 13:507-512, 1964

46. Skeith MD, Healey LA, Cutler RE: Urate excretion during mannitol and glucose diuresis. J Lab Clin Med 70:213-220, 1967

47. Gray G, Fogel R: Nutritrional aspects of dietary carbohydrates in R. Goodhart and M. Shils (eds): Modern Nutrition in Health and Disease, ed 6. Philadelphia, Lea and Febiger, 1978, pp $99-112$ 